\title{
SUBSTANSI KOMPONEN KOMPETENSI GURU SEKOLAH INKLUSIF BAGI ANAK BERKELAINAN/ BERKEBUTUHAN PENDIDIKAN KHUSUS
}

\author{
Sari Rudiyati \\ Jurusan PLB FIP UNY \\ sarirudiyati@yahoo.com
}

\begin{abstract}
Abstrak
Penelitian ini bertujuan untuk menghasilkan: (1) substansi komponen kompetensi guru sekolah inklusif bagi anak berkelainan/ berkebutuhan pendidikan khusus; dan (2) buku panduan dan instrumen asesmen kompetensi guru sekolah inklusif bagi anak berkelainan/berkebutuhan pendidikan khusus. Penelitian ini merupakan penelitian pengembangan dengan menggunakan prosedur research and development yang dikembangkan oleh Borg dan Gall (1983: 771-787).Teknik pengumpulan data penelitian ini adalah: (a) Teknik Delphi, (b) Focus Group Discussion, (c) angket/kuesioner, (d) wawancara, (e) portofolio guru, (f) observasi, dan (g) Studi dokumentasi. Analisis instrumen menggunakan Explanatory Factors Analysis dan Cronbach Alpha serta analisis data mengggunakan teknik deskriptif. Temuan hasil penelitian menunjukkan bahwa substansi komponen kompetensi guru sekolah inklusif bagi anak berkelainan meliputi kompetensi guru, kompetensi pedagogik, kompetensi sosial dan profesional. Produk penelitian yang berupa buku panduan dan instrumen dinilai mudah digunakan untuk melakukan asesmen kompetensi guru sekolah inklusif. Secara umum opini yang diberikan Kepala Sekolah Dasar Inklusif menunjukkan bahwa keberadaan model yang dikembangkan ini, dapat membantu pihak sekolah dalam hal penyediaan instrumen asesmen kompetensi guru sekolah inklusif bagi anak berkelainan/berkebutuhan pendidikan khusus.
\end{abstract}

Kata kunci: Substansi komponen kompetensi guru, sekolah inklusif, anak berkelainan/berkebutuban pendidikan kbusus

Substansi Komponen Kompetensi Guru Sekolab Inklusif - 533

Sari Rudiyati 
Jurnal Penelitian dan Evaluasi Pendidikan

\title{
SUBSTANTIAL COMPONENTS OF TEACHER'S COMPETENCE OF INCLUSIVE SCHOOL FOR EXEPTIONAL CHILDREN/ CHILDREN WITH SPECIAL EDUCATIONAL NEEDS
}

\author{
Sari Rudiyati \\ Jurusan PLB FIP UNY \\ sarirudiyati@yahoo.com
}

\begin{abstract}
The purposes of this research were to : (1) formulate substantial competence components of teachers of inclusive schools for exceptional children/children with special educational needs; and (2) develop a guide book and some competence assessment instruments of teachers of inclusive schools for exceptional children/children with special educational needs. The research was a developmental research study which used research and development procedures developed by Borg and Gall (1983: 771-787).The data gathering technique in this research included: (a) the Delphi technique, (b) focus group discussion, (c) questionnaire, (d) interview, (e) teachers' portfolios (f) observation, and (g) document study. The instrument analyses applied The Exploratory Factor Analyses and Cronbach Alpha, while the data analyses used a descriptive technique. The result of the research showed that the substantial components of teachers competence for inclusive schools for exceptional children/children with special educational needs included: teachers' competence, pedagogic competence, social competence, and professional competence. The research product in a form of a guiding book and instruments was seen as easy to use for assessing the competence of inclusive school teachers. Generally, the principals of the inclusive schools stated that the existence of the developed model would be able to assist the school in providing assessment instrument for assessing the competence of teachers of inclusive schools for exceptional children/children with special educational needs.
\end{abstract}

Keywords: Substantial competence components, inclusive schools, exceptional children/children with educational needs

534 - Jurnal Penelitian dan Evaluasi Pendidikan Tahun 16, Nomor 2, 2012 


\section{Pendahuluan}

Pendidikan inklusif merupakan inti hak asasi manusia untuk memperoleh pendidikan. Konsekuensi logika hak ini adalah bahwa semua anak berhak menerima pendidikan tanpa mendiskriminasikan pada latar ketidakmampuan, etnik, agama, bahasa, gender, budaya, dan kondisi lain. Pelaksanaan pendidikan inklusif perlu ada sekolah inklusif. Salah satu tuntutan sekolah inklusif adalah kompetensi guru dalam memberikan layanan pendidikan bagi semua anak termasuk anak berkelainan/ berkebutuhan pendidikan khusus.

Sebagian besar $(86 \%)$ guru tidak dilatarbelakangi pengetahuan tentang anak berkelainan/berkebutuhan pendidikan khusus, sehingga memerlukan kompetensi khusus dalam pelaksanaan pendidikan inklusif di Sekolah Dasar. Dalam Peraturan Menteri Pendidikan Nasional No. 16 th 2007 belum ada kompetensi khusus guru sekolah inklusif bagi anak berkelainan/berkebutuhan pendidikan khusus.

Salah satu upaya mengatasi permasalahan tersebut di atas adalah dengan melakukan penelitian tentang kompetensi guru sekolah inklusif bagi anak berkelainan/ berkebutuhan pendidikan khusus. Untuk itu perlu instrumen asesmen kompetensi guru sekolah inklusif bagi anak berkelainan/berkebutuhan pendidikan khusus yang sampai saat ini belum tersedia. Oleh karena itu penelitian pengembangan komponen kompetensi guru sekolah inklusif bagi anak berkelainan/berkebutuhan pendidikan khusus penting dilakukan. Dengan demikian diharapkan tersedianya panduan dan instrumen asesmen kompetensi guru sekolah inklusif bagi anak berkelainan/berkebutuhan pendidikan khusus.

Falvery dalam Dingle (2004:36) menyatakan bahwa:

"Inclusive schools have been described as schools in which the importance and value of diversity is showns troughout the entire school culture and within all programs".

Ini berarti bahwa sekolah inklusif dapat dideskripsikan sebagai sekolah yang dalam hal-hal penting dan nilai-nilai keberagaman ditunjukkan melalui 
seluruh budaya dan dalam semua program sekolah. Selain itu menurut Atta, Sahah, \& Khan (2007: 272-273):

Inclusive school is school where all children are tanght to understand and appreciate buman differences. Teacher and administrators receive the support necessary to include all students in regular education classrooms. Parents concerns for their children are taken gravely. Supportive learning and peer instruction are strategies used throughout the school. Where all kids are given the opportunity to develop real friends, not just peer buddies or helpers. In inclusive school the entire community honors diversity and supports quality education for student.

Mengenai pendapat ini dapat ditegaskan bahwa sekolah inklusif adalah sekolah dimana semua siswa diajar untuk memahami dan mengapresiasi perbedaan manusia. Guru dan admistrator mendapat dukungan yang diperlukan untuk memasukkan semua anak dalam kelas pendidikan reguler. Kepedulian orang tua untuk anak-anak mereka merupakan hal yang sangat penting. Dukungan belajar dan pembelajaran teman sebaya adalah strategi yang dapat digunakan melalui sekolah; dimana semua anak diberikan kesempatan untuk mengembangkan teman-teman nyata, tidak hanya sebagai teman baik atau penolong. Dalam sekolah inklusif seluruh komunitas menghargai keberagaman dan mendukung kualitas pendidikan untuk siswa.

Seterusnya menurut the Salamanca Framework for Action (Unesco, 1994:1) mengenai sekolah Inkusif dapat disampaikan bahwa:

The fundamental principle of the inclusive school is that all children should learn together, wherever possible, regardless of any difficulties or differences they may have. Inclusive schools must recognize and respond to the diverse needs of their students, accommodating both different styles and rates of learning and ensuring quality education to all through appropriate curricula, organizational arrangements, teaching strategies, resource use and partnerships with their communities. There should be a continuum of support and services to match the continuum of special needs encountered in every school. 
Dengan demikian prinsip-prinsip fundamental sekolah inklusif adalah bahwa semua anak sebaiknya belajar bersama, apapun kemungkinannya, tanpa mempedulikan kesulitan atau perbedaan apapun yang mungkin mereka miliki. Selain itu sekolah inklusif harus mengenali dan menanggapi terhadap keanekaragaman kebutuhan dari siswa mereka, mengakomodasi kedua perbedaan gaya dan kecepatan belajar dan menjamin kualitas pendidikan untuk semua melalui kurikulum yang tepat, pengorganisasian pengelolaaan, strategi mengajar, penggunaan sumber dan kemitraan dengan komunitas mereka. Ada kesinambungan dukungan dan layanan untuk memadukan keberlangsungan dalam menghadapi kebutuhan khusus setiap sekolah.

Dalam The Salamanca Statement and Framework for Action on Special Needs Education (1994:1), dinyatakan bahwa :

Inclusive education means that: "... schools should accommodate all children regardless of their physical, intellectual, social, emotional, linguistic or other conditions. This should include disabled and gifted children, street and working children, children from remote or nomadic populations, children from linguistic, ethnic or cultural minorities and children from other disadvantaged or marginalised areas or groups."

Sekolah inklusif berarti sekolah yang melaksanakan pendidikan inklusif mengakomodasi semua anak tanpa menghiraukan kondisi fisik, intelektual, sosial, emosional, linguistik atau kondisi lain mereka. Hal ini termasuk anak berkelainan/berkebutuhan pendidikan khusus dan anak berbakat, anak jalanan dan anak pekerja, anak dari populasi terpencil dan pengembara, anak dari minoritas linguistik, etnik dan budaya dan anakanak yang mempunyai kelemahan atau kelompok marginal lain. Dalam penelitian ini dibatasi pada anak-anak berkelainan/berkebutuhan pendidikan khusus saja.

Dalam buku Exceptional Children and Youth, menurut William Cruickshank dan G. Orville Jonhson (1958:3), pengertian anak berkelainan:

"Essentially, an exceptional child is one who deviates intellectually, physically, socially or emotionally, so markedly from what is considered to 
be normal growth and development that he cannot receive maximum benefit from a regular school program and requires a special class or supplementary instruction and services".

Menurut McAshan dalam Mulyasa (2003 : 38) pengertian kompetensi adalah

".....is a knowledge, skills, and abilities or capabilities that a person achieves, which become part of his or her being to the exent he or she can satisfactorily perform particular cognitive, afective, and psychomotor behaviors".

Dengan demikian kompetensi guru diartikan sebagai pengetahuan, keterampilan dan kemampuan atau kapabilitas yang dikuasai seseorang yang berprofesi sebagai guru; yang telah menjadi bagian darinya, sehingga yang bersangkutan dapat menampilkan perilaku-perilaku utama kognitif, afektif dan psikomotor sebagai seorang guru, termasuk guru sekolah inklusif bagi anak berkelainan/berkebutuhan pendidikan khusus. Komponen kompetensi guru sekolah inklusif yang dikembangkan dalam penelitian ini adalah komponen kompetensi khusus guru reguler sekolah inklusif bagi anak berkelainan/ berkebutuhan pendidikan khusus, yang meliputi komponen-komponen kompetensi pedagogik, kepribadian, sosial dan profesional.

Tujuan penelitian ini adalah: (1) Menghasilkan substansi komponen kompetensi guru sekolah inklusif bagi anak berkelainan/berkebutuhan pendidikan khusus. (2) Menghasilkan buku panduan dan instrumen asesmen kompetensi guru sekolah inklusif bagi anak berkelainan/ berkebutuhan pendidikan khusus yang teruji dan layak digunakan.

\section{Metode Penelitian}

Penelitian ini merupakan penelitian pengembangan yang secara konseptual dan prosedural, mengadopsi model: Educational Research and Development yang dikembangkan oleh Borg dan Gall (1983: 771-787).

Sepuluh langkah penelitian dan pengembangan Model Borg dan Gall hanya dilaksanakan 9 langkah. Langkah ke 10 yaitu implementasi dan 
diseminasi belum peneliti lakukan. Pokok-pokok kegiatan yang diadopsi dari Borg and Gall (1983) dengan langkah-langkah kegiatan yang dapat divisualisasikan sebagai berikut :

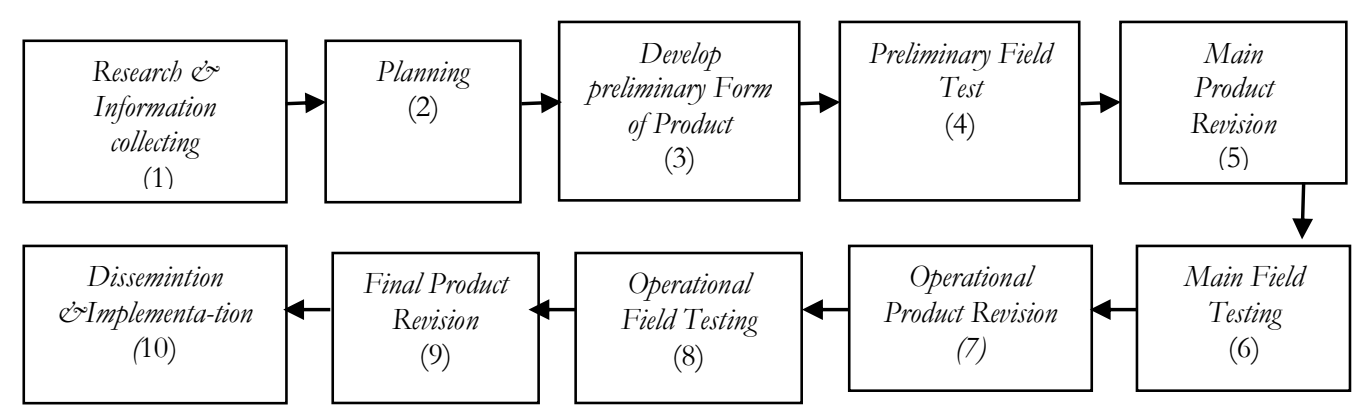

Gambar 1. Langkah-langkah umum siklus penelitian dan pengembangan

Borg \& Gall (1983) yang diadopsi untuk pengembangan substansi komponen kompetensi guru sekolah inklusif bagi AB/ABPK

Desain uji coba produk pengembangan substansi komponen kompetensi guru sekolah inklusif bagi anak berkelainan/berkebutuhan pendidikan khusus dapat disajikan pada Gambar 2.

Subyek coba dalam penelitian ini adalah para pakar dan praktisi pendidikan dan mengacu pada tahap-tahap yang dilakukan Borg dan Gall ( 1983; 775), yakni; dilakukan tiga tahap. Tahap pertama sebagai uji coba pendahuluan atau "preliminary field testing" dikenakan pada 30, 42, dan 25 subyek coba. Tahap kedua sebagai uji coba utama atau "main field testing" dikenakan pada 50 subyek coba, dan tahap ketiga sebagai subjek operasional atau "operational field testing" yang dikenakan pada 125 subyek coba. Penelitian ini dilaksanakan mulai bulan Agustus 2010 sd. November 2011 di sekolah-sekolah dasar inklusif di Daerah Istimewa Yogyakarta.

Berdasarkan pada tujuan pengembangan, maka untuk memperoleh data dalam penelitian ini digunakan beberapa teknik pengumpulan data, yakni : (a) Teknik Delphi, (b) Focus Group Discussion, (c) Angket/kuesioner, (d) wawancara, (e) Portofolio guru, (f) observasi, dan (g) Studi 
dokumentasi. Teknik analisis data digunakan Exploratory factor analysis (EFA), Alpha Cronbach dan analisis deskriptif.

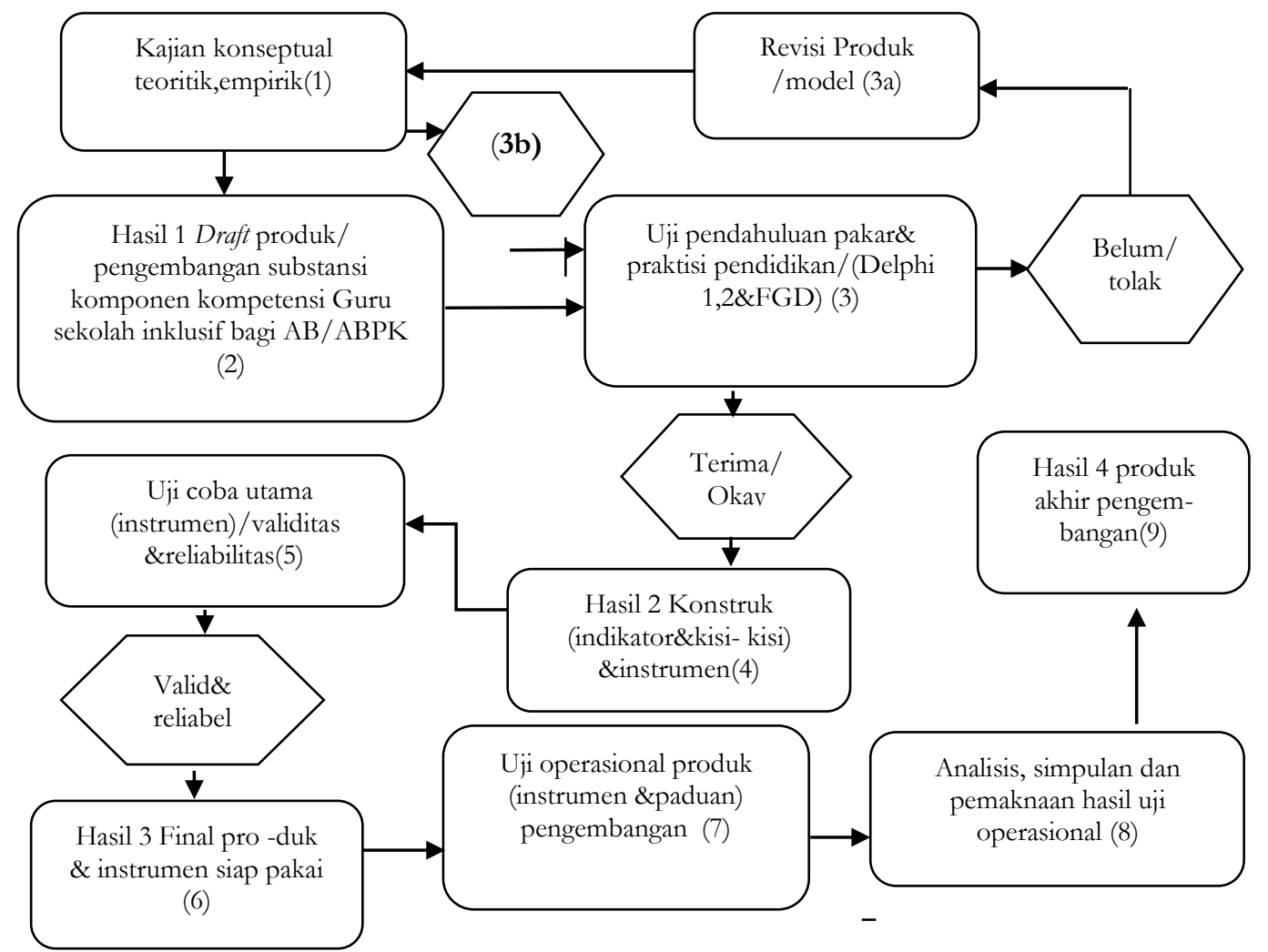

Gambar 2. Desain Ujicoba Produk Pengembangan Substansi KomponenKompetensi Guru Sekolah Inklusif AB/BPK

\section{Hasil dan Pembahasan}

Pengembangan substansi kompetensi guru sekolah inklusif bagi anak berkelainan/berkebutuhan pendidikan khusus dilakukan melalui kajian teoritik, empirik, dan praktik di lapangan. Selain itu pengembangan substansi komponen kompetensi guru sekolah inklusif bagi anak 
berkelainan/berkebutuhan pendidikan khusus yang dihasilkan telah dikaji melalui proses panjang seperti diskusi panel, seminar instrumen, teknik Delphi, diskusi kelompok terfokus (FGD) dan uji coba produk di lapangan.

Diskusi panel dan seminar instrumen dilakukan dengan para pakar dan praktisi pendidikan dan mengikutsertakan mahasiswa S3 Program Studi Penelitian dan Evaluasi Pendidikan (PEP), dosen pembina program studi PEP, para promotor disertasi dan pengelola Program Pascasarjana UNY. Teknik Delphi mengajak para pakar dan praktisi pendidikan secara nasional terbatas. Diskusi kelompok terfokus (FGD) dilaksanakan dengan menghadirkan pakar dan praktisi pendidikan; dan ujicoba produk dilakukan terhadap respoden yang lebih luas seperti pakar dan praktisi pendidikan.

Proses penelitian dan pengembangan yang direncanakan secara sistematik, ternyata membutuhkan waktu lama, namun pada akhirnya dapat diperoleh substansi komponen dan indikator kompetensi guru sekolah inklusif bagi anak berkelainan/berkebutuhan pendidikan khusus yang digunakan sebagai acuan dalam mengembangkan instrumen penelitian sekaligus sebagai instrumen asesmen kompetensi guru sekolah inklusif bagi anak berkelainan/berkebutuhan pendidikan khusus.

Fokus temuan penelitian dan pengembangan untuk mendapatkan substansi komponen kompetensi guru sekolah inklusif bagi anak berkelainan/berkebutuhan pendidikan khusus yang memiliki kelayakan dalam menetapkan substansi komponen kompetensi guru sekolah inklusif bagi anak berkelainan/ berkebutuhan pendidikan khusus; dilakukan antara lain dengan menggunakan teknik Delphi, yakni melalui curah pendapat, komentar, masukan dan saran-saran untuk memperoleh kesepakatan/ konsensus dan judgment.

Para pakar dan praktisi pendidikan yang berasal dari berbagai institusi dan latar belakang, sebagai peserta Delphi dipilih untuk berpartisipasi melakukan penilaian terhadap tingkat pentingnya substansi komponen dan indikator-indikator kompetensi yang diajukan peneliti. Secara teknis, teknik Delphi dilakukan dalam dua putaran dengan menggunakan fasilitas PO BOX 119 YKBS 55281 A selama tiga bulan sebagai media alamat surat menyurat dan didukung dengan media telpon seluler dan e-mail. 
Responden Delphi yang telah dilibatkan untuk berpartisipasi dalam putaran pertama adalah 40 orang peserta, sedangkan surat dan instrumen yang kembali pada peneliti hanya berasal dari 30 orang peserta. Kegiatan Delphi putaran pertama dimulai pada tanggal 10 Februari 2011 sampai dengan 10 Maret 2011. Instrumen dibagikan kepada para peserta Delphi untuk memperoleh respon dengan menilai setiap substansi komponen dan indikator kompetensi guru sekolah inklusif bagi anak berkelainan/ berkebutuhan pendidikan khusus yang diajukan; peserta juga diberi kesempatan untuk menyampaikan saran, pendapat, komentar dan masukan tentang substansi komponen kompetensi guru sekolah inklusif bagi anak berkelainan/berkebutuhan pendidikan khusus yang dikembangkan. Berdasarkan penilaian, saran, pendapat, komentar dan masukan yang telah diberikan, seterusnya pengembang melakukan konfirmasi dan atau klarifikasi tentang hasil Delphi beserta saran, pendapat, komentar dan masukan yang telah disampaikan peserta Delphi untuk memperoleh klarifikasi. Hasil Delphi putaran pertama antara lain adalah bahwa tingkat pentingnya substansi komponen dan indikator kompetensi profesional guru sekolah inklusif bagi anak berkelainan/berkebutuhan pendidikan khusus (Delphi putaran pertama) mencapai 91,25\%; jadi sudah melebihi kriteria kelayakan yang telah ditetapkan sebesar 80\%; namun demikian pendapat, komentar, masukan dan saran-saran untuk memperoleh konsensus tetap menjadi pertimbangan peneliti. Besaran persentase serta saran-saran dan masukan yang telah diberikan, digunakan peneliti sebagai dasar untuk mengembangkan substansi kompetensi guru sekolah inklusif bagi anak berkelainan/berkebutuhan pendidikan khusus, selanjutnya digunakan untuk mengembangkan instrumen Delphi pada putaran kedua.

Secara kuantitatif semua substansi komponen dan indikator kompetensi guru sekolah inklusif bagi anak berkelainan/berkebutuhan pendidikan khusus telah memenuhi indikator yang ditetapkan yaitu telah mencapai 90,88\%, namun demikian substansi komponen dan indikator yang telah dibenahi mengalami perubahan, yakni dari 4 komponen kompetensi dan 28 indikator kompetensi berubah menjadi 4 komponen kompetensi dan 34 indikator kompetensi. 
Substansi komponen dan indikator kompetensi sekolah inklusif bagi anak berkelainan/berkebutuhan pendidikan khusus untuk Delphi putaran kedua dibagikan kembali kepada peserta Delphi agar diberikan penilaian dalam rangka memperoleh kesepakatan/konsensus. Responden Delphi putaran kedua yang dimulai pada 20 Maret sampai sampai dengan 16 April 2011 dengan mengundang 60 peserta, sedangkan jumlah peserta yang mengembalikan instrumen baik melalui surat maupun diambil secara langsung adalah 42 orang peserta.

Tingkat pentingnya substansi komponen dan indikator kompetensi sosial guru sekolah inklusif bagi anak berkelainan/berkebutuhan pendidikan khusus untuk Delphi putaran kedua mencapai 94,04\%, jadi sudah melebihi kriteria kelayakan yang telah ditetapkan sebesar 90\%; namun demikian pendapat, komentar, masukan dan saran-saran untuk memperoleh konsensus masih tetap menjadi pertimbangan peneliti. Instrumen Delphi putaran kedua yang dibagikan kepada peserta Delphi diharapkan memperoleh respon dengan menilai setiap substansi komponen dan indikator kompetensi guru sekolah inklusif bagi anak berkelainan/berkebutuhan pendidikan khusus yang diajukan, selain itu peserta Delphi juga diberikan kesempatan untuk menyampaikan saran, komentar dan pendapatnya terhadap pengembangan substansi yang telah diperbaiki atau direvisi.

Respon positif tetap diberikan peserta Delphi, komentar yang menyatakan bahwa substansi komponen kompetensi putaran dua lebih representatif dari sisi substansi komponen dan indikator kompetensi guru sekolah inklusif bagi anak berkelainan/berkebutuhan pendidikan khusus, hanya saja beberapa pakar mengatakan bahwa substansi komponen kompetensi guru sekolah inklusif bagi anak berkelainan/berkebutuhan pendidikan khusus yang baru terlalu ideal, yakni menawarkan sebuah konsep yang mungkin sulit dicapai para guru sekolah inklusif. Untuk itu, pada tataran teknik implementasi di lapangan, ketika substansi komponen dan 543 indikator kompetensi guru sekolah inklusif bagi anak berkelainan/ berkebutuhan pendidikan khusus dikembangkan menjadi instrumen pengumpul data tidaklah cukup hanya dengan sebuah angket; para pakar menyarankan kepada pengembang untuk mengamati secara langsung 
kondisi persekolahan inklusif, baik pada setting kegiatan belajar di ruangruang kelas maupun pada seluruh kegiatan belajar yang terjadi di sekolah inklusif.

Berdasarkan penilaian dan saran yang diberikan, langkah selanjutnya pengembang melakukan diskusi lanjut dengan peserta Delphi untuk memperoleh kejelasan pada substansi kompetensi guru sekolah inklusif bagi anak berkelainan/berkebutuhan pendidikan khusus yang baru. Hasil ini sebagai draft akhir substansi kompetensi guru sekolah inklusif bagi anak berkelainan/berkebutuhan pendidikan khusus.

Kriteria yang digunakan untuk menetapkan apakah substansi komponen dan indikator kompetensi guru sekolah inklusif bagi anak berkelainan/berkebutuhan pendidikan khusus memiliki kelayakan sebagai substansi kompetensi guru sekolah inklusif bagi anak berkelainan/ berkebutuhan pendidikan khusus layak; apabila memperoleh penilaian di atas $90 \%$, dan hasil penilaian yang telah dicapai seluruh komponen kompetensi adalah 93,97\%. Secara kuantitatif semua substansi komponen dan indikator kompetensi guru sekolah inklusif bagi anak berkelainan/ berkebutuhan pendidikan khusus memenuhi kriteria yang ditetapkan. Kajian teoritik, empirik, dan praktik di lapangan serta diskusi intensif dengan promotor disertasi dan berbagai pihak melalui uji coba di lapangan menunjukkan bahwa substansi komponen kompetensi guru sekolah inklusif bagi anak berkelainan/berkebutuhan pendidikan khusus yang baru, menawarkan substansi komponen dan indikator yang lebih komprehensif, yakni konsep yang lebih padat, komprehensif, dan terintegrasi berisi 4 komponen dan 34 indikator kompetensi sebagai produk akhir dari hasil penelitian dan pengembangan ini.

Setelah teknik Delphi putaran kedua telah direvisi maka hasilnya didiskusikan dalam Focus Group Discussion (FGD). Dalam penelitian ini FGD diselenggarakan dengan tujuan untuk mendiskusikan dan memantapkan hasil teknik Delphi mengenai substansi komponen dan indikator kompetensi guru sekolah inklusif, serta memperoleh judgment dari para pakar terhadap draft produk yang berupa buku panduan dan instrumen yang dikembangkan. Peserta Focus group Discussion (FGD) adalah orangorang yang dipandang memiliki kemampuan dan kepakaran dalam bidang 
yang dijadikan fokus penelitian dan pengembangan ini, yaitu masalah pengembangan substansi komponen kompetensi guru sekolah inklusif bagi anak berkelainan/berkebutuhan pendidikan khusus, dengan demikian mampu memberikan sumbangan pemikiran, yaitu para ahli bidang pendidikan khusus/Pendidikan Luar Biasa, manajemen pendidikan, penelitian dan evaluasi pendidikan, psikologi pendidikan, teknologi pendidikan, para pengawas, asesor sekolah dan kepala sekolah. Peserta FGD ini adalah 25 orang yang berbeda dengan peserta Delphi, dan tiap peserta juga diberi kebebasan untuk menyampaikan pendapatnya, khususnya tentang substansi komponen dan indikator kompetensi guru sekolah inklusif.

Hasil Focus group Discussion (FGD) tentang draft produk yang berupa buku panduan dan instrumen pengembangan substansi komponen dan indikator kompetensi guru sekolah inklusif bagi anak berkelainan/berkebutuhan pendidikan khusus dikatakan layak apabila memenuhi kriteria kelayakan. Kriteria yang digunakan untuk menetapkan apakah draft produk (buku panduan dan instrumen) pengembangan substansi komponen dan545indikator kompetensi guru sekolah inklusif bagi anak berkelainan/berkebutuhan pendidikan khusus memiliki kelayakan sebagai produk pengembangan substansi komponen dan indikator kompetensi guru sekolah inklusif bagi anak berkelainan/berkebutuhan pendidikan khusus; apabila memperoleh judgment dari para pakar dengan cara penilaian baik dan sangat baik dijumlahkan, memperoleh hasil di atas 90\%. Hasil penilaian yang telah dicapai adalah: komprehensif $20 \%+74,67 \%=94,67 \%$, praktis $44 \%+49,33 \%=93,33 \%$, efisien dan obyektif $50,40 \%+41,60 \%=92 \%$. Setelah dilakukan analisis dengan prosentase pada masing-masing kategori kriteria, maka substansi komponen dan indikator kompetensi guru sekolah inklusif bagi anak berkelainan/berkebutuhan pendidikan khusus dapat dinyatakan memiliki kelayakan sebagai instrumen pengembangan. Masukan dan saran-saran yang diberikan dalam FGD, digunakan juga sebagai dasar untuk mengembangkan instrumen pengembangan substansi komponen kompetensi guru sekolah inklusif yang digunakan sebagai instrumen 
asesmen untuk menetapkan kompetensi guru sekolah inklusif bagi anak berkelainan/berkebutuhan pendidikan khusus.

Indikator-indikator yang seterusnya disusun menjadi butir-butir instrumen diterima sebagai hasil FGD, digunakan sebagai dasar penyusunan instrumen penelitian pengembangan substansi komponen kompetensi guru sekolah inklusif bagi anak berkelainan/berkebutuhan pendidikan khusus. Produk akhir pengembangan berupa panduan dan instrumen asesmen kompetensi guru sekolah inklusif bagi anak berkelainan/berkebutuhan pendidikan khusus dilampirankan pada akhir naskah disertasi.

Berdasarkan saran, masukan dan komentar yang diberikan melalui uji coba pendahuluan, baik yang diberikan pada naskah secara langsung, maupun pada lembar saran, maka draft produk yang berupa buku panduan dan instrumen asesmen kompetensi guru sekolah inklusif bagi anak berkelainan/berkebutuhan pendidikan khusus telah diperbaiki. Selanjutnya hasil perbaikan pada instrumen pengembangan substansi kompetensi guru sekolah inklusif bagi anak berkelainan/berkebutuhan pendidikan khusus digunakan sebagai dasar dalam membenahi instrumen asesmen kompetensi guru sekolah inklusif bagi anak berkelainan/berkebutuhan pendidikan khusus pada uji coba utama.

Uji coba utama di lapangan atau main field testing diterapkan pada 50 subyek coba. Pada tahap ini diharapkan draft produk pengembangan yang berupa buku panduan dan instrumen asesmen kompetensi guru sekolah inklusif, sudah lebih baik dan siap diujicobakan pada skala yang lebih luas. Pada tahap ujicoba utama ini diterapkan pada subyek coba yang terdiri dari subyek penelitian yaitu 40 orang guru umum/reguler, dan sumber informasi lain tentang guru yaitu 5 orang Guru Khusus, 5 Kepala Sekolah dari lima Sekolah Dasar Inklusif. Dalam uji coba utama ini, selain subyek coba diminta pendapatnya tentang kelayakan instrumen berupa angket sebagai pengumpul data, juga diminta untuk menilai kompetensi guru sekolah inklusif bagi anak berkelainan/berkebutuhan pendidikan khusus melalui pertanyaan yang diberikan dalam bentuk butir-butir pernyataan. Uji coba utama ini sekaligus untuk menguji kelayakan instrumen. Untuk 
membuktikan validitas konstruk digunakan Exploratory Factor Analysis dan uji reliabilitas menggunakan Cronbach Alpha.

Pengujian validitas dan reliabilitas instrumen dilakukan guna mengukur sejauhmana instrumen dapat memenuhi kriteria validitas dan reliabilitas. Dalam penelitian ini, uji validitas dilakukan menggunakan Exploratory Factor Analysis (EFA). Analisis Faktor Exploratori atau Exploratory Factor Analysis (EFA) adalah teknik untuk mereduksi data yang digunakan untuk mengetahui apakah konsep yang telah disusun berdasarkan kajian teori dan telah diuji secara empirik, didukung data atau tidak. Teknik ini juga dapat digunakan untuk mengestimasi validitas dan reliabilitas instrumen (Badrun Kartowagiran, 2007: 8). Analisis dengan EF $A$ ini digunakan untuk menguji apakah suatu konstruk dapat dijelaskan oleh indikator-indikatornya. Apabila indikator-indikator dapat membentuk konstruk atau variabel, maka ditunjukkan dengan nilai loading factor yang tinggi, diharapkan nilai Kaiser-Meyer-Olkin Measure of Sampling (KMO) lebih besar dari 0.5. (Hair, JF., 2006: 37).

Tabel 1. Rekapitulasi Hasil Uji Instrumen Kompetensi Guru Sekolah Inklusif bagi AB/ABPK

\begin{tabular}{|l|c|c|c|}
\hline \multicolumn{1}{|c|}{ Variabel } & KMO & $\begin{array}{c}\text { Signifikansi } \\
\text { Chi Square }\end{array}$ & Status \\
\hline Kompetensi Pedagogik & 0,516 & 0,000 & kecukupan data terpenuhi \\
\hline Kompetensi Kepribadian & 0,790 & 0,000 & kecukupan data terpenuhi \\
\hline Kompetensi Sosial & 0,763 & 0,000 & kecukupan data terpenuhi \\
\hline Kompetensi Profesional & 0,608 & 0,000 & kecukupan data terpenuhi \\
\hline Kompetensi Gabungan & 0,684 & 0,000 & kecukupan data terpenuhi \\
\hline
\end{tabular}

Berdasarkan tabel di atas diketahui bahwa hasil pengujian signifikansi keseluruhan dengan uji Barlett diperoleh nilai signifikansi masing-masing variabel dan gabungan sebesar 0,000 atau $<0,05$. Oleh karena nilai signifikansi tersebut $<0,05$ maka dapat disimpulkan bahwa sekumpulan butir yang digunakan dinyatakan signifikan dan dapat diproses lebih lanjut. 
Uji kecukupan sampel diperoleh nilai KMO untuk masing-masing dan gabungan variabel sebesar $>0,5$. Oleh karena nilai KMO tersebut lebih besar dari batas yang direkomendasikan yaitu $>0,5$ maka analisis faktor dapat dilanjutkan ke tahap berikutnya yaitu memeriksa muatan faktor dan pola muatan faktor.

Kompetensi guru sekolah inklusif bagi anak berkelainan/ berkebutuhan pendidikan khusus ( $\mathrm{AB} / \mathrm{ABPK})$ terdiri dari empat komponen kompetensi, yaitu komponen kompetensi pedagogik, komponen kompetensi kepribadian, komponen kompetensi sosial, dan komponen kompetensi profesional terdiri dari 34 indikator, 108 deskriptor dan 108 butir.

Dari hasil analisis dapat diketahui bahwa hampir semua butir yaitu 102 dari 108 gabungan butir memenuhi kriteria memiliki muatan faktor $>0,50$, karena hanya butir-butir b4a dan b11b dari komponen kompetensi pedagogik, serta butir b4a, b5a, b7b dan b8d dari komponen kompetensi profesional saja yang belum memenuhi kriteria memiliki muatan faktor $>0,50$, hampir semua butir terseleksi memiliki muatan faktor $>0,50$ dan masuk dalam komponen kepribadian, sosial, pedagogik, dan profesional. Dengan demikian pertanyaan penelitian telah terjawab, dan validitas instrumen telah teruji. Butir-butir yang belum memenuhi kriteria telah direvisi dan digunakan dalam uji operasional.

Tabel 2. Rekapitulasi hasil uji reliabilitas instrumen kompetensi guru sekolahinklusif bagi anak berkebutuhan pendidikan khusus

\begin{tabular}{|l|c|c|}
\hline \multicolumn{1}{|c|}{ Variabel } & Nilai Alpha & Status \\
\hline Kompetensi Pedagogik & 0,961 & Reliabel \\
\hline Kompetensi Kepribadian & 0,966 & Reliabel \\
\hline Kompetensi Sosial & 0,835 & Reliabel \\
\hline Kompetensi Profesional & 0,938 & Reliabel \\
\hline $\begin{array}{l}\text { Kompetensi (gabungan) Guru } \\
\text { Sekolah Inklusif bagi AB/ABPK }\end{array}$ & 0,925 & Reliabel \\
\hline
\end{tabular}

548 - Jurnal Penelitian dan Evaluasi Pendidikan Tahun 16, Nomor 2, 2012 
Dalam menginterpretasikan indeks reliabilitas indikator terhadap variabel laten digunakan 0,7 (Nunally, J,C., 1978: 193) sudah cukup baik untuk reliabilitas hasil penelitian. Reliabiltas dari skor total tes dapat diestimasikan dengan koefisiensi $\alpha$ (Alpha) minimal sebesar 0,66 (Allen \& Yen (1979: 80). Dalam penelitian ini indeks reliabilitas yang digunakan adalah minimal 0,7 , dengan predikat baik. Berdasarkan hasil pengujian terhadap seluruh butir pertanyaan yang ada sebagaimana diketahui bahwa nilai Alpha secara keseluruhan $>0,7$ sehingga dapat disimpulkan bahwa instrumen kuesioner tersebut adalah reliable.

Interpretasi hasil uji reliabilitas dilakukan dengan melihat nilai alpha. Jika nilai Alpha suatu instrumen kuesioner $>0,7$, maka dapat disimpulkan bahwa instrumen kuesioner tersebut adalah reliabel. Sebaliknya jika nilai alpha suatu butir $<0,7$, maka disimpulkan bahwa instrumen kuesioner tersebut tidak reliabel. Berdasarkan hasil pengujian terhadap seluruh butir pertanyaan yang ada sebagaimana pada tabel di atas, diketahui bahwa nilai Alpha secara keseluruhan $>0,7$, sehingga dapat disimpulkan bahwa instrumen kuesioner tersebut adalah reliabel.

Dalam uji operasional kelayakan dari produk pengembangan yang berupa instrumen yang dikembangkan dalam penelitian ini diuji secara empirik. Kelayakan diukur dari kemampuan instrumen ini dalam mengidentifikasi substasi komponen dan indikator kompetensi guru, yang selanjutnya dapat digunakan untuk melakukan asesmen kompetensi guru sekolah dasar inklusif bagi anak berkelainan/berkebutuhan pendidikan khusus. Dalam uji coba operasional ini digunakan 9 buah sekolah dasar inklusif sebagai sampel penelitian, yaitu SD Tumbuh Yogyakarta, SDN Giwangan Yogyakarta, SDN Pojok, Sleman, SDN Gejayan, Sleman, SDN Kadipiro I Bantul, SDIT Baitussalam Prambanan, SDN Gedangan Gunung Kidul, SD Muhammadiyah Sumberejo, SD Karangmojo III, Gunung Kidul.

Temuan hasil penelitian menunjukkan bahwa pengembangan substansi komponen kompetensi guru sekolah inklusif bagi anak berkelainan dinilai sebagai model yang layak: (1) Instrumen valid dan reliabel (konstrak teori cocok dengan data empiris dan didukung oleh semua indikator). (2) Komprehensif, memiliki empat komponen dan 34 
indikator sebagai kriteria untuk menetapkan kompetensi guru sekolah inklusif bagi anak berkelainan/berkebutuhan pendidikan khusus. (3) Holistik, dapat mengungkap fakta yang terjadi sesungguhnya di lapangan. (4) Model ini dapat mengidentifikasi substansi komponen kompetensi yang masih perlu ditingkatkan dari guru sekolah inklusif bagi anak berkelainan/berkebutuhan pendidikan khusus.(a) Komponen kompetensi pedagogik termasuk dalam kategori cukup $(2,67)$, nilai tersebut berada pada rentang skor $\operatorname{cukup}(>2,6$ hingga 3,4); (b) Komponen kompetensi kepribadian termasuk dalam kategori baik $(3,47)$, nilai tersebut berada pada rentang skor baik (>3,4 hingga 4,2); (c) Kompetensi sosial termasuk dalam kategori cukup $(2,702)$, nilai tersebut berada pada rentang skor cukup $(>2,6$ hingga 3,4); (d) Komponen kompetensi profesional termasuk dalam kategori kurang $(2,59)$, nilai tersebut berada pada rentang skor kurang $(>1,80$ hingga 2,6). (5) Produk penelitian yang berupa buku panduan dan instrumen dinilai mudah digunakan untuk melakukan asesmen kompetensi guru sekolah inklusif. Secara umum opini yang diberikan Kepala Sekolah Dasar Inklusif menunjukkan bahwa keberadaan model yang dikembangkan ini, dapat membantu pihak sekolah dalam hal penyediaan instrumen asesmen kompetensi guru sekolah inklusif bagi anak berkelainan/ berkebutuhan pendidikan khusus.

\section{Simpulan}

Berdasarkan pembahasan hasil penelitian yang dilakukan, maka dapat disimpulkan, sebagai berikut:

1. Produk pengembangan substansi komponen kompetensi guru sekolah inklusif bagi anak berkelainan dapat dinilai sebagai produk yang layak, hal ini dibuktikan dengan instrumen yang valid dan reliabel (konstrak teori cocok dengan data empiris dan didukung oleh semua indikator).

2. Kelayakan dari produk yang dikembangkan dalam penelitian ini juga diukur dari kemampuan produk dalam mengidentifikasi substansi komponen dan indikator kompetensi guru yang selanjutnya dapat digunakan untuk melakukan asesmen terhadap kompetensi guru 
sekolah dasar inklusif bagi anak berkelainan/berkebutuhan pendidikan khusus.

3. Berdasarkan hasil analisis data dapat disimpulkan bahwa pengembangan substansi komponen kompetensi guru sekolah inklusif bagi anak berkelainan dinilai sebagai produk yang teruji dan layak, karena hal-hal sebagai berikut:

a. Komprehensif, memiliki empat komponen dan 34 indikator sebagai kriteria untuk menetapkan kompetensi guru sekolah inklusif bagi anak berkelainan/berkebutuhan pendidikan khusus.

b. Holistik, dapat mengungkap fakta yang terjadi sesungguhnya di lapangan, dengan menggunakan berbagai cara dalam pelaksanaannya.

c. Hasil penilaian pakar dan praktisi pendidikan menunjukkan bahwa produk pengembangan substansi komponen kompetensi guru sekolah inklusif bagi anak berkelainan/berkebutuhan pendidikan khusus efektif, praktis, dan panduan dinilai layak sebagai acuan implemen -tasi produk di lapangan

d. Produk ini dapat mengidentifikasi substansi komponen kompetensi yang masih perlu ditingkatkan dari guru sekolah inklusif bagi anak berkelainan/berkebutuhan pendidikan khusus.

4. Hasil penelitian yang menunjukkan adanya beberapa substansi komponen kompetensi guru yang perlu segera ditingkatkan. Komponen kompetensi tersebut meliputi: (a) Komponen kompetensi pedagogik yang termasuk dalam kategori cukup $(2,67)$, nilai tersebut berada pada rentang skor cukup (>2,6 hingga 3,4); (b) Komponen kompetensi kepribadian yang termasuk dalam kategori baik $(3,47)$, nilai tersebut berada pada rentang skor baik ( $>3,4$ hingga 4,2); (c) Komponen kompetensi sosial yang termasuk dalam kategori cukup $(2,70)$, nilai tersebut berada pada rentang skor cukup ( $>2,6$ hingga 3,4); (d) Komponen kompetensi profesional yang termasuk dalam kategori kurang $(2,59)$, nilai tersebut berada pada rentang skor kurang $(>1,80$ hingga 2,6).

5. Produk penelitian yang berupa buku panduan dan instrumen dinilai mudah digunakan untuk melakukan asesmen kompetensi guru sekolah 
Jurnal Penelitian dan Evaluasi Pendidikan

inklusif. Secara umum opini yang diberikan Kepala Sekolah Dasar Inklusif menunjukkan bahwa keberadaan model yang dikembangkan ini, dapat membantu pihak sekolah dalam hal penyediaan instrumen asesmen kompetensi guru sekolah inklusif bagi anak berkelainan/ berkebutuhan pendidikan khusus.

\section{Daftar Pustaka}

Allen, K. E. 1980. Mainstreaming in early childhood education. New York: Delmar Publisher Inc.

Allen, Mary., \& Yen, Wend. 1979. Introduction to measurement theory. California: Brooks/Cole Publishing Company.

Atta, A. M, Mahmood, S., \& M. Mumtaz, K. 2007. Inclusive school and inclusive teacher. The Dialogue Journal, 4, 2.

Badrun Kartawagiran. 2007. Analisis faktor. Yogyakarta: Lembaga Penelitian Universitas Negeri Yogyakarta.

, Walter, R \& Gall, Mredith D. 1983. Educational research (An Introduction, $4^{\text {th }}$ Edition) London: Longman Inc.

Cronbach, L.J. 1970. Essentials of Psychological Testing. 3rd edition. New York: Harper and Row.

Cruickshank,W.M. 1958. Psychology of exceptional children and youth. Englewood Cliffs, New Jersey: Printice-Hall.

Hair, J.F. Anderson, RE., Tatham, R.T., \& Black, W.C. 1978. Multivariate data analysis. (5 ${ }^{\text {th }} \mathrm{ed}$.). London: Prentice-Hall International.

Nunally, J,C. 1978. Psychometric theory. New York: McGraw Hill Book Company.

UNESCO. 1994. Final report: World conference on special needs education: acces and quality. Paris: UNESCO.

552 - Jurnal Penelitian dan Evaluasi Pendidikan Tahun 16, Nomor 2, 2012 